\title{
Familial selective malabsorption of vitamin $B_{12}$
}

\author{
MARY BELL, J. T. HARRIES, O. H. WOLFF, A. M. DAWSON, and A. H. WATERS \\ From The Hospital for Sick Children, Great Ormond Street, and St. Bartholomew's Hospital, London
}

\begin{abstract}
Bell, M., Harries, J. T., Wolff, O. H., Dawson, A. M., and Waters, A. H. (1973). Archives of Disease in Childhood, 48, 896. Familial selective malabsorption of vitamin $B_{12}$. A patient with selective malabsorption of vitamin $B_{12}$ is described who differs in certain respects from previously published cases. Steatorrhoea was severe and was reversed by $B_{12}$ therapy, proteinuria was absent, and $\mathrm{B}_{12}$ malabsorption was also present in one of the parents.

The differences between our patient and other reported cases probably represent a wide disease spectrum rather than a different disease entity. This being so, our patient is the first case where unequivocal vitamin $B_{12}$ malabsorption has been shown in one of the parents.
\end{abstract}

In 1960, Imerslund in Norway and Gräsbeck and colleagues in Finland independently described the familial occurrence of megaloblastic anaemia in children due to an isolated defect of vitamin $B_{12}$ absorption. Proteinuria was also a common finding in the affected children. Since then several workers in other countries have reported cases of selective $\mathrm{B}_{12}$ malabsorption with proteinuria (Table I).

Both Imerslund and Gräsbeck et al. emphasized the familial nature of the disease and speculated that the abnormality in $\mathrm{B}_{12}$ absorption was ganetically determined and present from birth. Family studies of patients in published reports suggest an autosomal recessive mode of inheritance. Attempts to define a heterozygous carrier state in the parents and sibs of affected children by measuring their ability to absorb small oral doses of radioactive $B_{12}$ have so far been unrewarding.

The paper describes a patient with selective $B_{12}$ malabsorption who differs in some respects from previously reported cases. It also reports the results of $B_{12}$ absorption studies carried out on both parents and a brother of the patient.

\section{Case report}

Past history. The patient is the second child of healthy unrelated English parents. Pregnancy was uneventful and he was born at term weighing $4 \mathrm{~kg}$. There was no relevant family history. A left cleft lip and palate were repaired at 4 months. Except for mild flexural eczema he remained in good health until the age of 5 years, when he developed severe recurrent mouth

Received 29 May 1973. ulcers which persisted despite treatment with many topical agents, and were responsible for much loss of schooling. At the age of 6 years both his weight and height were between the 25th and 50th centiles, but by 15

\section{TABLE I}

Summary of published cases of selective $B_{12}$ malabsorption *

\begin{tabular}{|c|c|c|c|}
\hline Authors & Year & Country & No. of cases \\
\hline $\begin{array}{l}\text { Najman and Brausil } \\
\text { Imerslund } \\
\text { Gräsbeck et al. } \\
\text { Colle, Greenterg, and } \\
\text { Krivit } \\
\text { Lamy et al. } \\
\text { Wise, Lovric, and } \\
\text { O'Gorman-Hughes } \\
\text { Sievens } \\
\text { Spurling, Sacks, and Jiji } \\
\text { Chavelet et al. } \\
\text { de Sousa } \\
\text { Mohammed, McKay, } \\
\text { and Galloway } \\
\text { Smrhova, Wiedermann, } \\
\text { and Wiedermann } \\
\text { Hippe } \\
\text { Castel et al. } \\
\text { Anttila and Salmi } \\
\text { Gorin, Salama, and } \\
\text { Guillien } \\
\text { Grăsbeck and Kvist } \\
\text { Lillibridge, Brandborg, } \\
\text { anc' Rubin } \\
\text { Furuhjelm and Kojo } \\
\text { Ben-Basset, Feinstein, } \\
\text { and Ramot } \\
\text { Mackenzie et al. }\end{array}$ & $\begin{array}{l}1952 \\
1960 \\
1960 \\
1961 \\
1961 \\
1963 \\
1964 \\
1964 \\
1964 \\
1966 \\
1966 \\
1966 \\
1966 \\
1966 \\
1967 \\
1967 \\
1967 \\
1967 \\
1968 \\
1969 \\
1972\end{array}$ & $\begin{array}{l}\text { Yugoslavia } \\
\text { Norway } \\
\text { Finland } \\
\text { U.S.A. } \\
\text { France } \\
\text { Australia } \\
\text { Denmark } \\
\text { U.S.A. } \\
\text { France } \\
\text { Portugal } \\
\text { Great Britain } \\
\text { Czechoslovakia } \\
\text { Denmark } \\
\text { France } \\
\text { Finland } \\
\text { France } \\
\text { Finland } \\
\text { U.S.A. } \\
\text { Finland } \\
\text { Israel } \\
\text { U.S.A. }\end{array}$ & $\begin{array}{r}1 \\
10 \\
2 \\
1 \\
2 \\
1 \\
1 \\
2 \\
1 \\
2 \\
2 \\
1 \\
1 \\
3 \\
2 \\
1 \\
19+ \\
6 \\
17 \\
18 \\
3\end{array}$ \\
\hline
\end{tabular}

* Modified from Visakorpi and Furuhjelm (1968). tIncluding previously described cases. 
years they had fallen to below the 3rd centile. During this period of growth retardation there were no gastrointestinal symptoms and, except during periods of mouth ulceration, his appetite was good. Pallor was not noted.

Present admission. $\mathrm{He}$ was referred to The Hospital for Sick Children at the age of 14 years 9 months because of recurrent mouth ulcers and short stature. He was a depressed boy whose height $(146.5 \mathrm{~cm})$ and weight $(35.5 \mathrm{~kg})$ were both below the $3 \mathrm{rd}$ centile. There were no signs of puberty and, except for a few small sublingual ulcers, physical examination was normal, and no neurological abnormalities were found.

Investigations. $\mathrm{He}$ had a megaloblastic anaemia due to $\mathrm{B}_{12}$ deficiency. The haematological findings are summarized in Table II.

TABLE II

\section{Haematological findings}

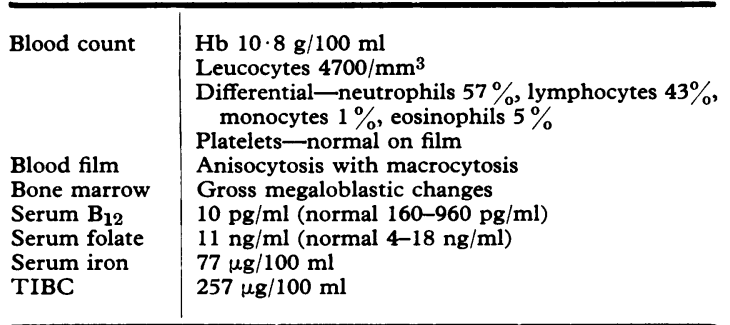

TIBC, total iron binding capacity.

There were no antibodies in the serum to thyroid, gastric parietal cells, or intrinsic factor. Serum $B_{12}$ concentration was $10 \mathrm{pg} / \mathrm{ml}$ and unsaturated $B_{12}$ binding capacity $2200 \mathrm{pg} / \mathrm{ml}$. The proportion of serum binding due to the $\beta$-fraction, which contains transcobalamin II, was $66 \%$, and that due to the $a$-fraction containing transcobalamin I, was $34 \%$. These results are similar to those found in patients with severe $B_{12}$ deficiency due to causes other than pernicious anaemia (Herbert, 1968).

Gastric juice was acid ( $p \mathrm{H} \mathrm{2 \cdot 8)}$ with normal intrinsic factor activity by the method of Ardeman and Chanarin (1963)-before and after stimulation with pentagastrin 44 and 96 units $/ \mathrm{ml}$, respectively. A Schilling test showed severe $B_{12}$ malabsorption $(2 \cdot 7 \%$ of a $1 \mu \mathrm{g}$ oral dose of ${ }^{57} \mathrm{Co}-\mathrm{B}_{12}$ excreted in 24 hours), which was not improved by the addition of hog intrinsic factor $(2.6 \%$ excreted in 24 hours). Quantitative cultures of duodenal juice for aerobic and anaerobic bacteria showed a normal flora, and urinary excretion of indoles was not increased.

Faecal fat excretion was grossly abnormal (76 $\mathrm{g}$ fat excreted over 5 days). Xylose excretion was normal (34\% of $5 \mathrm{~g}$ loading dose excreted in urine in 24 hours). Barium meal and follow-through showed slight dilatation of duodenum and proximal jejunum with normal appearance of distal small intestine. Peroral biopsy (2 weeks after starting $B_{12}$ therapy) showed the duodenal mucosa to be normal under light microscopy. Liver function tests (serum bilirubin, transaminases, and serum albumin), and pancreatic function tests (sweat sodium and chloride concentration; fasting trypsin, lipase, and amylase activities in duodenal juice after pancreazymin-secretin stimulation) were normal. Plasma vitamins $\mathrm{A}$ and $\mathrm{E}$ levels, plasma calcium, inorganic phosphorus, and alkaline phosphatase were all within the normal range.

Sensitive tests of renal tubular and glomerular function, namely urinary lysozyme excretion by the method of Barratt and Crawford (1970), and urinary albumin measured by an immunochemical technique on several occasions, were normal. In addition, blood urea, creatinine clearance, and intravenous pyelography were also normal.

Management. He was given $1000 \mu \mathrm{g} \mathrm{B} \mathrm{B}_{12}$ weekly for 3 weeks by intramuscular injection. This produced a complete haematological remission. His mood improved and he became less depressed and truculent, and more co-operative. The mouth ulcers disappeared. $\mathrm{He}$ was discharged on a maintenance dose of $250 \mu \mathrm{g} \mathrm{B}_{12}$ monthly.

Follow-up. 6 months later he was admitted for reassessment. The improvement in mood had been maintained, the mouth ulcers had not recurred, and growth velocity had increased from below the 3 rd centile to between the 10th and 25th centiles. Faecal fat excretion had returned to normal $(11 \cdot 3 \mathrm{~g}$ fat excreted over 5 days), and the radiological abnormalities in the small intestine had disappeared. Despite this improvement there was no change in $B_{12}$ absorption. The patient excreted $2.9 \%$ of a $1 \mu \mathrm{g}$ dose of ${ }^{57} \mathrm{Co}-\mathrm{B}_{12}$ given with hog intrinsic factor, and when the test was repeated with intrinsic factor and $50 \mathrm{ml}$ normal human duodenal juice there was no change, $2.5 \%$ of the dose being excreted in 24 hours.

Since then he has remained in excellent health, and at the age of $17 \frac{1}{2}$ years signs of puberty appeared, and height and weight were between the 3rd and 10th centiles. $B_{12}$ malabsorption persists and maintenance therapy remains necessary. The mouth ulcers have not recurred.

Family studies. Vitamin $B_{12}$ absorption was measured in both parents and a brother. A double isotope modification of the Schilling test was used (Bayly, Bell, and Waters, 1971) and the results are summarized in Table III. The severe malabsorption of $B_{12}$ in the patient was confirmed by this method. The father also had unequivocal malabsorption of $B_{12}$ (though less severe than the patient), which was not corrected by intrinsic factor. $\mathbf{B}_{12}$ absorption was normal in the brother, and results in the mother were at the lower end of the normal range.

Serum $B_{12}$ concentrations measured by Lactobacillus leichmannii assay were normal in the father $(315 \mathrm{pg} / \mathrm{ml})$, mother (355 pg/ml), and brother $(330 \mathrm{pg} / \mathrm{ml})$. 
TABLE III

Family $B_{12}$ absorption studies ${ }^{\star}$

\begin{tabular}{|c|c|c|c|c|}
\hline Subjects & $\begin{array}{l}\text { Age } \\
\text { (yr) }\end{array}$ & $\begin{array}{c}\text { Date of } \\
\text { test }\end{array}$ & $\begin{array}{l}{ }^{58} \mathrm{Co}-\mathrm{B}_{12} \\
\text { alone } \\
\text { (\% excretion } \\
\text { in } 24 \mathrm{hr} \text { ) }\end{array}$ & $\begin{array}{l}{ }^{57} \mathrm{Co}-\mathrm{B}_{12} \\
\text { IF bound } \\
\text { ( } \% \text { excretion } \\
\text { in } 24 \mathrm{hr} \text { ) }\end{array}$ \\
\hline Patient & $15 \frac{1}{2}$ & 4 Sept 1969 & $1 \cdot 2$ & $1 \cdot 5$ \\
\hline Father & 50 & 18 Mar 1970 & $\begin{array}{l}1 \cdot 3 \\
6 \cdot 6 \\
6 \cdot 8\end{array}$ & $\begin{array}{l}1 \cdot 3 \\
6 \cdot 3 \\
5 \cdot 6\end{array}$ \\
\hline Mother & 55 & 18 Mar 1970 & $13 \cdot 2$ & $15 \cdot 7$ \\
\hline Brother & $12 \frac{1}{2}$ & $18 \operatorname{Mar} 1970$ & $20 \cdot 1$ & $18 \cdot 8$ \\
\hline
\end{tabular}

*Two capsules containing, respectively, $0.25 \mu \mathrm{g}{ }^{58} \mathrm{Co}-\mathrm{B}_{12}$ and $0.25 \mu \mathrm{g}{ }^{57} \mathrm{Co}-\mathrm{B}_{12}$ bound to normal human gastric juice were taken simultaneously and followed immediately by intra-muscular injection of $1 \mathrm{mg}$ nonradioactive $B_{12}$. Urine was collected for $24 \mathrm{hr}$. Control subjects excrete equal amounts of the two isotopes in the range $13-36 \%$ of the administered dose.

IF, intrinsic factor.

\section{Discussion}

The present case has several features which are similar to those described in other patients with the syndrome of selective $B_{12}$ malabsorption. He had severe $B_{12}$ deficiency, megaloblastic anaemia, and $B_{12}$ malabsorption that could not be corrected with either hog or human intrinsic factor. Free acid was present in the gastric juice and intrinsic factor secretion was normal by in vitro assay. Tests for serum antibodies against intrinsic factor, gastric parietal cells, and thyroid were all negative.

Certain features, however, distinguish our patient from previously reported cases. The absence of generalized malabsorption is one of the diagnostic criteria of this syndrome. Though slight abnormalities of small bowel structure and function may occur (Visakorpi and Furuhjelm, 1968), we are not aware of such severe steatorrhoea having been previously reported. This was reversible, however, and faecal fat excretion had returned to normal when measured after 6 months of $B_{12}$ therapy. The initial dilatation of the proximal small bowel had also disappeared. These changes are probably due to the effect of severe $B_{12}$ deficiency on the small intestine. Similar reversible changes in the absorption of vitamin $B_{12}$ itself have been reported in patients with severe $B_{12}$ deficiency (Schloesser and Schilling, 1963; Haurani, Sherwood, and Goldstein, 1964; Brody, Estren, and Herbert, 1966; Mollin and Waters, 1968).

Proteinuria, sometimes associated with renal tract abnormalities, is almost invariably an integral part of the syndrome. Several examinations of urine by sensitive techniques failed to reveal increased amounts of albumin in our patient.

The late diagnosis of megaloblastic anaemia requires some explanation. Most cases have presented with megaloblastic anaemia in the first 2 years of life, presumably at a time when maternally derived stores of $\mathrm{B}_{12}$ are depleted. Though the exact diagnosis has often been delayed for several years (Gräsbeck et al., 1960; Ben-Basset et al., 1969), such patients have usually received $B_{12}$ or folic acid therapy. As far as is known, our patient received no $B_{12}$ or folate therapy until the diagnosis was first made at the age of 14 years 9 months. The early onset of growth failure and mouth ulcers, however, suggested that $B_{12}$ deficiency had been present for several years, and it is possible that bone marrow examination at an earlier age would have revealed megaloblastosis even though there were no signs of anaemia. A possible explanation is that the dietary folate intake was enough to prevent the onset of anaemia in spite of the associated $\mathrm{B}_{12}$ deficiency. It is also possible that the slow rate of growth may have spared the available $B_{12}$ for haemopoiesis, and thereby delayed the onset of anaemia; a similar explanation has been suggested for the absence of overt megaloblastic anaemia in coeliac children with folate deficiency (Dormandy, Waters, and Mollin, 1963).

Mouth ulcers have been reported in two other children with selective $B_{12}$ malabsorption (Colle et al., 1961; Mackenzie et al., 1972). This was the presenting feature in our patient who suffered from severe recurrent mouth ulcers over a period of 10 years. This caused considerable loss of schooling. The ulcers disappeared with $B_{12}$ therapy and have not recurred.

Familial occurrence is a striking feature of the syndrome of selective $B_{12}$ malabsorption, and family studies of patients in published reports suggest an autosomal recessive mode of inheritance (Gräsbeck and Kvist, 1967; Visakorpi and Furuhjelm, 1968). Attempts have been made to define a heterozygous carrier state by measuring $\mathrm{B}_{12}$ absorption in the parents and sibs of affected children, but the results have so far been unrewarding. Normal $B_{12}$ absorption (assessed by Schilling tests) has been reported in the parents of several cases (Gräsbeck $e t$ al., 1960; Chavelet et al., 1964; Spurling et al., 1964; Ben-Basset et al., 1969; Mackenzie et al., 1972). Mohammed et al. (1966) found abnormal $\mathbf{B}_{12}$ absorption in the father of one of their patients, but when subsequently reassessed, the Schilling test was normal. However, in the father of our patient, $\mathbf{B}_{12}$ absorption was abnormal on two separate occasions, and in the mother the results were at the lower end of the normal range. The test was normal in a brother. These findings are consistent with an autosomal recessive mode of inheritance. 


\section{Familial selective malabsorption of vitamin $B_{12}$}

The nature of the absorptive defect in selective $B_{12}$ malabsorption has not been defined, though evidence points to the ileal mucosa as the most likely site of the lesion. Patients with this condition secrete normal amounts of biologically active intrinsic factor (Gräsbeck et al., 1960; Imerslund and Bjornstad, 1963; Mackenzie et al., 1972), there are no circulating antibodies to intrinsic factor or the $\mathrm{B}_{12}$-IF complex (Gräsbeck and Kvist, 1967; Mackenzie et al., 1972), and the $B_{12}$ carrier proteins in plasma are not deficient (Gräsbeck and Kvist, 1967; Mackenzie et al., 1972). The absorption of small doses of radioactive- $B_{12}$ is not improved by the addition of normal jejunal juice (Bjornstad and Imerslund, 1963; Spurling et al., 1964; Gräsbeck and Kvist, 1967) or by administration of broad spectrum antibiotics (Imerslund and Bjornstad, 1963). All these observations point towards the ileal mucosa as the site of the defect in $B_{12}$ absorption. Examination of ileal biopsies by light or electron microscopy has revealed no morphological abnormality (Gräsbeck and Kvist, 1967; Visakorpi and Furuhjelm, 1968; Mackenzie et al., 1972). It has been suggested that there may be a lack of specific ileal receptors for the $B_{12}$-IF complex (Herbert, 1960; Gräsbeck and Kvist, 1967). Mackenzie et al. (1972), however, showed that uptake of $B_{12}$-IF by a homogenized ileal biopsy from a patient with selective $B_{12}$ malabsorption was normal, which argues strongly against the lack of ileal receptors. Furthermore, serum from three of their patients with selective $B_{12}$ malabsorption did not impair the uptake of $B_{12}$-IF by guinea-pig ileum brush-border preparations, suggesting that there were no antibodies against ileal receptors. These observations led Mackenzie et al. (1972) to suggest that the defect in $B_{12}$ absorption occurs after attachment of $B_{12}$-IF to the ileal mucosa, but before the absorbed $B_{12}$ binds to its carrier protein (transcobalamin II).

\section{REPBRENCES}

Anttila, R., and Salmi, H. A. (1967). Selective malabsorption of vitamin $\mathbf{B}_{1.2}$ with proteinuria in children. (Abst.) Proceedings of the Fifteenth Northern Pediatric Congress, Bergen. Acta Paediatrica Scandinavica, 56, Suppl., 90.

Ardeman, S., and Chanarin, I. (1963). A method for the assay of human gastric intrinsic factor and for the detection and titration of antibodies against intrinsic factor. Lancet, $2,1350$.

Barratt, T. M., and Crawford, R. (1970). Lysozyme excretion as a measure of renal tubular dysfunction in children. Clinical Science, 39, 457.

Bayly, R. J., Bell, T. K., and Waters, A. H. (1971). A duel isotope modification of the Schilling test. Proceedings of the Society of Nuclear Medicine, 7th Annual Meeting, Zurich, p. 911. Schattauer, Stuttgart and New York.

Ben-Basset, I., Feinstein, A., and Ramot, B. (1969). Selective vitamin $\mathbf{B}_{12}$ malabsorption with proteinuria in Israel. Clinical and genetic aspects. Israel fournal of Medical Sciences, 5, 62.
Bjornstad, P., and Imerslund, O. (1963). Studies of patients with familial vitamin $B_{12}$ malabsorption. The lack of effect of normal intestinal juice on the absorption of vitamin $\mathbf{B}_{12}$. Acto Haematologica, 30, 340 .

Brody, E. A., Estren, S., and Herbert, V. (1966). Coexistent pernicious anaemia and malabsorption in four patients: including one whose malabsorption disappeared with vitamin $B_{12}$ therapy. Annals of Internal Medicine, 64, 1246.

Castel, Y., Najean, Y., Pacreau, B., Chapuis, G., Saleum, G., Mollaret, J., and Jonqueur, A. (1966). La malabsorption spécifique de la vitamın $B_{12}$ avec protéinurie: anémie pernicieuse d'Imerslund-Najinan-Gräsbeck. Trois observations dans la même fratrie. Ouest Médical, 19, 573.

Chavelet, F., Najean, Y., Ravailleau, J., Grenet, P., and Bernard, J. (1964). Etude d'un cas d'anémie pernicieuse de l'enfant avec activité facteur intrinséque normale du suc gastrique. Nouvelle Révue Française d'Hématologie, 4, 311.

Colle, E., Greenberg, L., and Krivit, W. (1961). Studies of a patient with selective deficiency in absorption of vitamin $B_{12}$ Blood, 18, 48

de Sousa, C. S. (1966). La mala absorción especifica de vitamina $\mathrm{B}_{12}$. Revista Española de Pediatria, 22, 117.

Dormandy, K. M., Waters, A. H., and Mollin, D. L. (1963). Folic-acid deficiency in coeliac disease. Lancet, 1, 632.

Furuhjelm, U., and Kojo, N. (1968). Selective vitamin $B_{12}$ malabsorption. A clinical study. Quoted as in preparation in Visakorpi, J. K., and Furuhjelm, U. (1968).

Gorin, R., Salama, C., and Guillien, F. (1967). A propos d'un nouveau cas d'anémie par malabsorption spécifique de la vitamine $B_{12}$ avec proténurie: étude des anémies mégaloblastiques de l'enfant par avitaminose $\mathrm{B}_{12}$ primitive. Annales de Pédiatrie, 14, 1383.

Gräsbeck, R., Gordin, R., Kantero, I., and Kuhlbăck, B. (1960) Selective vitamin $B_{12}$ malabsorption and proteinuria in young people. A syndrome. Acta Medica Scandinavica, 167, 289.

Gräsbeck, R., and Kvist, G. (1967). La malabsorption congénitale et sélective de la vitamine $B_{12}$ avec protéinurie. Europa Medica, $3,3$.

Haurani, F. I., Sherwood, W., and Goldstein, F. (1964). Intestinal malabsorption of vitamin $B_{12}$ in pernicious anemia. Metabolism, 13, 1342.

Herbert, V. (1960). Mechanism of absorption of vitamin $B_{12}$ Federation Proceedings, 19, 884.

Herbert, V. (1968). Diagnostic and prognostic values of measurement of serum vitamin $B_{12}$ binding proteins. Blood, 32, 305.

Hippe, E. (1966). Malabsorption of vitamin $B_{12}$. Report of a case in a 1-year-old boy, including studies of the absorption of $B_{12}$ Acta Paediatrica Scandinavica, 55, 510.

Imerslund, O. (1960). Idiopathic chronic megaloblastic anemia in children. Acta Paediatrica, 49, Suppl. 119.

Imerslund, O., and Bjornstad, P. (1963). Familial vitamin $B_{12}$ malabsorption. Acta Haematologica, 30, 1.

Lamy, M., Besancon, F., Loverdo, A., and Afifi, F. (1961). Le malabsorption spécifique de la vitamine $\mathrm{B}_{12}$ avec protéinurie. Etude de quatre cas. Archives Françaises de Pédiatrie, 18, 1109.

Lillibridge, C. B., Brandborg, L. L., and Rubin, C. E. (1967) Childhood pernicious anemia. Gastrointestinal secretory, histological, and electron microscopic aspects. Gastroenterology, 52, 792

Mackenzie, I. L., Donaldson, R. M., Trier, J. S., and Mathan, V. I. (1972). Ileal mucosa in familial selective vitamin $B_{12}$ malabsorption. Nero England fournal of Medicine, 286, 1021.

Mohammed, S. D., McKay, E., and Galloway, W. H. (1966) Juvenile familial megaloblastic anaemia due to selective malabsorption of vitamin B12. Quarterly Fournal of Medicine, 35, 433.

Mollin, D. L., and Waters, A. H. (1968). Nutritional megaloblastic anaemia. In Occurrence, Causes and Prevention of Nutritional Anaemias, p. 121. Ed. by G. Blix. Swedish Nutrition Foundation, Symposium No. 6. Almqvist and Wiksell, Uppsala.

Najman, E., and Brausil, B. (1952). Megaloblastische anămie mit relapsen ohne achylia gastrica im kindesalter. Annales Paediatrici, 178, 47.

Schloesser, L. L., and Schilling, R. F. (1963). Vitamin $B_{12}$ absorption studies in a vegetarian with megaloblastic anemia. American fournal of Clinical Nutrition, 12, 70.

Sievens, C. J. (1964). Megaloblastic anemia in a 3 year old child. Blood, 23, 547 
Smrhova, I. Wiedermann, M., and Wiedermann, B. (1966). Megaloblastische anămie als folge einer selektiven vitamin- $\mathrm{B}_{12^{-}}$ malabsorption. Folia Haematologica, 86, 70.

Spurling, C. L., Sacks, M. S., and Jiji, R. M. (1964). Juvenile pernicious anemia. New England fournal of Medicine, 271, 995.

Visakorpi, J. K., and Furuhjelm, U. (1968). Sel ctive malabsorption of vitamin $B_{12}$. In Modern Problems in Pediatrics, Vol. II. Intestinal Absorption and Malabsorption, p. 150. (Bibliotheca Paediatrica No. 87). Ed. by D. H. Shermerling, H. Berger, and A. Prader. Karger, Basle and New York.
Wise, G. A., Lovric, V. A., and O'Gorman-Hughes, D. W. (1963). Some experiences with the syndrome of megaloblastic anaemia in infancy. Medical fournal of Australia, 2, 877.

Correspondence to Dr. J. T. Harries, Department of Child Health, Institute of Child Health, 30 Guilford Street, London WC1N 1EH. 